DOI 10.31558/2307-2318.2019.4.14

\title{
УДК:331.108.45
}

Сивицька І. Г., к.е.н., доцент кафедри бізнес-статистики та економічної кібернетики ДонНУ імені Василя Стуса

Синиченко А. В., ст.викладач кафедри менеджменту та поведінкової економіки ДонНУ імені Василя Стуса

\section{ФОРМУВАННЯ СИСТЕМИ ПЕРСОНІФІКОВАНОГО НАВЧАННЯ В УПРАВЛІННІ РОЗВИТКОМ КЛІЕНТООРІЕНТОВАНОСТІ ПЕРСОНАЛУ}

Стаття присвячена питанням побудови ефективної системи підвищення кваліфікації персоналу в області клієнтоорієнтованості, яка є невід'ємною частиною розвитку самих підприємств та підвищення якості послуг, які вони надають. Основу системи складають освітні процеси, спрямовані на підготовку працівника до професійної діяльності через оволодіння знаннями, навичками та вміннями, необхідними для виконання роботи, яка передбачається конкретною посадою й робочим місцем. Обгрунтовано необхідність та охарактеризовано особливості персоніфікованого підходу до розробки програм навчання персоналу. Реалізація даного підходу дозволяє спиратися на внутрішні ресурси та розробляти перспективні проекти професійно-особистісного зростання фахівців підприємства. Персоніфікований підхід передбачає складання профілю компетенцій для кожної посади та врахування особливостей навчання дорослих, перш за все, підвищені вимоги щодо якості та результатів навчання, а також можливість впливати на процес, темп, методи й засоби. Цикл навчання розглядається як частина загального процесу розвитку людських ресурсів підприємства. Запропоновано алгоритм розробки програми навчання, що починається 3 аналізу освітніх потреб персоналу, на основі якого відбувається розробка корпоративної програми та визначення iii загального бюджету. Обов'язковим етапом після реалізації програми навчання є оцінка ефективності й результативності та посттренінговий супровід. В роботі запропоновано орієнтовну структуру навчального модуля, присвяченого клієнтоорієнтованості, що був апробований в рамках реалізації спеціальної програми підвищення кваліфікації для фітосанітарних інспекторів Головного управління Держпродспоживслужби у Вінницькій області, розробленої Донецьким національним університетом імені Василя Стуса. Отримані результати дослідження можуть бути використані на підприємствах різної форми власності 3 метою підвищення ефективності процесів організації професійної підготовки, перепідготовки та підвищення кваліфікації персоналу.

Ключові слова: розвиток персоналу, клієнтоорієнтованість, підвищення кваліфікації, персоніфікований підхід, програма навчання.

Рис. -1 , Табл. -1 , Літ. -11.

Сивицкая И. Г., Синиченко А. В.

ФОРМИРОВАНИЕ СИСТЕМЫ ПЕРСОНИФИЦИРОВАННОГО ОБУЧЕНИЯ В УПРАВЛЕНИИ РАЗВИТИЕМ КЛИЕНТООРИЕНТИРОВАННОСТИ ПЕРСОНАЛА

Статья посвящена вопросам построения эффективной системы повышения квалификации персонала в области клиентоориентированности, которая является неотъемлемой частью развития самих предприятий и повышения качества предоставляемых услуг. Основу системы составляют образовательные процессы, 
направленные на подготовку работника к профессиональной деятельности через овладение знаниями, навыками и умениями, необходимыми для выполнения работы, предусматриваемой конкретной должностью и рабочим местом. Обоснована необходимость и охарактеризованы особенности персонифицированного подхода к разработке программ обучения персонала. Реализация данного подхода позволяет опираться на внутренние ресурсы и разрабатывать перспективные проекты профессионально-личностного роста специалистов предприятия. Персонифицированный подход предусматривает составление профиля компетенций для каждой должности и учет особенностей обучения взрослых, прежде всего, повышенные требования к качеству и результатам обучения, а также возможность влияния на процесс, темп, методы и средства обучения. Цикл обучения рассматривается как часть общего процесса развития человеческих ресурсов предприятия. Предложен алгоритм разработки программы обучения, начиная с анализа образовательных потребностей персонала, на основе которого происходит разработка корпоративной программы и определение ее общего бюджета. Обязательным этапом после реализации программы обучения является оценка эффективности и результативности, а также посттренинговое сопровождение. В работе предложена примерная структура учебного модуля, посвященного клиентоориентированности, который был апробирован в рамках реализации специальной программы повышения квалификации для фитосанитарных инспекторов Главного управления Держпродспоживслужбы в Винницкой области, разработанной Донецким национальным университетом имени Василия Стуса. Полученные результаты исследования могут быть использованы на предприятиях различной формы собственности с целью повышения эффективности процессов организации профессиональной подготовки, переподготовки и повышения квалификации персонала.

Ключевые слова: развитие персонала, клиентоориентированность, повышение квалификации, персонифицированный подход, программа обучения.

\section{Syvytska I., Synychenko A. \\ ORGANIZATION OF A SYSTEM OF PERSONALIZED TRAINING IN MANAGING OF DEVELOPMENT OF CUSTOMER-ORIENTED STAFF}

The article is devoted to the issues of building an effective staff development system in the field of customer focus, which is an integral part of the development of enterprises themselves and improving the quality of their services. The basis of the system made by educational processes aimed to preparing the employee for professional activities through mastering the knowledge, skills and abilities necessary to perform the work provided by a specific position and workplace. The necessity is substantiated and the features of a personified approach to the development of personnel training programs are described. The implementation of this approach allows you to rely on internal resources and develop promising projects of professional and personal growth of the enterprise specialists. A personalized approach involves compiling a profile of competencies for each position and taking into account the characteristics of adult education, first of all, increased requirements for the quality and results of training, as well as the possibility of influencing the process, pace, methods and means of training. The training cycle is considered as part of the overall process of development of human resources of the enterprise. An algorithm for developing a training program is proposed, starting with an analysis of the educational needs of staff, on the basis of which a corporate program is developed and its overall budget is determined. An mandatory step after the implementation of the training program is to evaluate the effectiveness and efficiency, as well as post-training 
support. The work proposes an approximate structure of a training module on customer focus, which was tested as part of a special training program for phytosanitary inspectors of the Main Directorate of the State Service for Food Safety and Consumer Protection in the Vinnitsa Region, developed by the Vasil Stus Donetsk National University. The results of the study can be used at enterprises of various forms of ownership in order to increase the efficiency of the processes of organizing vocational training, retraining and advanced training of personnel.

Keywords: staff development, customer focus, advanced training, personalized approach, training program.

Постановка проблеми в загальному вигляді. В умовах глобалізації економіки, зростання невизначеності на внутрішньому й зовнішніх ринках успіх компанії визначається вже не стільки ефективним використанням ресурсів та рівнем витрат, скільки ефективністю взаємодії 3 ключовими клієнтами, здатністю до повного переформатування діяльності підприємства та всіх його елементів 3 метою виявлення та задоволення потреб споживача й формування спільними з ним зусиллями кінцевої споживчої цінності власного продукту. Це зумовило необхідність впровадження клієнтоорієнтованого підходу в якості провідної парадигми ведення господарської діяльності, як наслідок - особливі вимоги до персоналу сучасної організації та налагодження системи його безперервного розвитку.

Розвиток персоналу підприємства представляє комплексне, багатогранне поняття, яке охоплює широке коло економічних, соціальних, психологічних та організаційних проблем. Це цілеспрямований та систематичний вплив 3 метою удосконалення знань, умінь та навичок працівників підприємства, що реалізується через сукупність організаційно-економічних заходів. Основу системи розвитку персоналу складають інформаційні та освітні процеси прямого й непрямого підвищення кваліфікації співробітників, які пов'язані з конкретними посадами й робочими місцями. Розробка ефективної системи навчання клієнтоорієнтованості та впровадження іiі у діяльність вітчизняних суб'єктів господарювання можливе лише за умови попереднього створення грунтовного теоретичного та методичного забезпечення цього процесу.

Аналіз останніх досліджень та публікацій. Питанню розвитку персоналу присвячено багато наукових робіт зарубіжних та вітчизняних дослідників. Так, Есаулова І.А. досліджує еволюційні закономірності й тенденції, що обумовлюють зміну методології й практики розвитку людських ресурсів [1]. Дж. Гіллі запропонував модель індивідуального розвитку й управління ефективністю, спрямовану на виявлення бар'єрів, що перешкоджають працівникові в досягненні найвищих результатів [2]. В роботі [3] Д.Джой-Меттьюз, з співавторами досліджують поняття розвитку людських ресурсів, різні форми й методи цього процесу, методику оцінки та вимірювання результатів. В роботах українських вчених [4,5,6] Гугул О.Я., Плугіної Ю.А., Збрицької Т.П., Савченко Г.О., Татаревської М.С., також багато уваги приділяється аналізу існуючих підходів до визначення поняття «розвиток персоналу» й моделей розвитку персоналу.

Теоретико-методичні проблеми клієнотоорієнтованого менеджменту також останнім часом активно досліджуються й висвітлюються в публікаціях як зарубіжних так i вітчизняних видань. В роботах Моргулець О.Б. [7], досліджено сутність клієнтоорієнтованого підходу в управлінні підприємством та запропоновано авторську модель сервіс-менеджменту на основі процесного підходу. Продан I. О. [8] обгрунтовує взаємозв'язок клієнтоорієнтованості з конкурентоспроможністю компанії та проводить аналіз методики оцінки рівня клієнтоорієнтованості. Стаття Романчукевич М.Й. [9] 
присвячена розробці процесу упровадження клієнтоорієнтованої бізнес-стратегії в діяльність компанії.

Метою дослідження $\epsilon$ формалізація процесу розробки системи персоніфікованого навчання в управлінні розвитком клієнтоорієнтованості персоналу. Для досягнення поставленої мети визначено наступні наукові завдання: уточнення особливостей персоніфікованого підходу до навчання в контексті розвитку персоналу, розробка алгоритму формування програми навчання персоналу в управління розвитком клієнтоорієнтованості й вимог до змісту програми.

Виклад основного матеріалу дослідження. Під навчанням персоналу в управління клієнтоорієнтованістю будемо розуміти освітні процеси підвищення кваліфікації, спрямовані на розвиток професійних знань, умінь і навичок співробітників у сфері клієнтоорієнтованості, а також передачу досвіду ефективної поведінки в відповідних професійно значущих ситуаціях. Процес навчання не завжди однаковий за формою, змістом i способом організації та спрямований як на отримання вузькоспеціальних знань в сфері клієнтоорієнтованості, так і засвоєння загальних корпоративних цінностей компанії.

Зростаючу популярність в системах підвищення кваліфікації набуває сьогодні персоніфікований підхід, який передбачає інтеграцію в освітній процес принципів і технологій персоніфікації та реалізується в контексті підтримуючого навчання.

Персоніфікований підхід є об’єктивним й екологічним чинником розвитку процесу освіти на сучасному етапі [10]. Він грунтується на розумінні суб'єкта навчання як відкритої, складної системи, що володіє здатністю самоорганізовуватися й підтримувати себе в стані динамічної рівноваги. Цей підхід передбачає вимогу надавати особам, що навчаються, варіанти освітніх маршрутів і видів освітніх послуг відповідно до потреб, можливостей та кар'єрних перспектив. Реалізація персоніфікованого підходу в системі підвищення кваліфікації персоналу дозволяє спиратися на внутрішні ресурси співробітників i розробляти перспективні проекти їх професійно-особистісного зростання.

Таким чином, навчання персоналу в процесі впровадження системи підвищення клієнтоорієнтованості є частиною загального процесу розвитку людських ресурсів підприємства. Цикл навчання повинен представляти цілісний процес і включати в себе наступні етапи (рис.1):

1. Аналіз потреб персоналу в навчанні:

1.1. Аналіз існуючих розривів в діяльності персоналу: дослідження поведінки співробітників та відгуків клієнтів.

1.2. Визначення можливостей для покращення діяльності персоналу в сфері клієнтоорієнтованості, що не пов'язані з навчанням (мотивація, підбір персоналу, зміна посадових інструкцій).

1.3. Визначення пріоритетів навчання 3 урахуванням тимчасових обмежень i стратегічних цілей.

2. Розробка корпоративної програми навчання в сфері клієнтоорієнтованості персоналу:

2.1. Встановлення цілей навчальної програми, визначення цільової аудиторії.

2.2. Зміст програми навчання:

2.2.1. Вибір методики навчання (лекції, семінари, тренінги, навчання 3 використанням комп'ютерних програм і т. ін.). 
2.2.2. Розробка навчальних матеріалів (підручники, матеріали семінарів, комп'ютерні програми, презентації й інші матеріали, які будуть використовуватися в процесі навчання).

2.3. Визначення кількості учасників програми навчання із зазначенням функцій / підрозділів, які будуть ними представлені.

3. Бюджетування (визначення загального бюджету програми навчання).

3.1. Розробка вимог до місця проведення й допоміжного обладнання.

3.2. Визначення та відбір провайдера освітніх послуг (кваліфікаційні вимоги до викладачів-тренерів).

4. Реалізація програми навчання.

5. Оцінка програми та результативності навчання:

5.1. Визначення методів корпоративної й індивідуальної оцінки результатів навчання.

5.2. Визначення критеріїв оцінки якості навчання (оцінка тренера-викладача й змісту курсу).

6. Посттренінговий супровід.

Найважливішими принципами розробки програм навчання персоналу в системі управління розвитком клієнтоорієнтованості виступають:

- орієнтація на вирішення конкретних проблем в сфері клієнтоорієнтованості персоналу;

- організація навчання як складової процесу розвитку підприємства ;

- поєднання навчання з методами « неосвітнього» характеру ;

- використання нових освітніх технологій, методів і методик.

При розробці програми навчання необхідно враховувати особливості, пов'язані 3 процесом навчання дорослих [11].

У числі таких особливостей, що визначають ряд вимог як до організації навчального процесу, так і до викладача доцільно назвати наступні:

-дорослі вважають себе зрілими, автономними й незалежними, та, як наслідок, віддають перевагу навчанню, в якому мають можливість впливати на процес, темп, методи й засоби;

-мотивація до навчання дорослих пов'язана 3 їх практичними потребами й найважливішим мотиваційним фактором виступає можливість використання отриманих знань і досвіду на практиці, особливо, в ситуаціях змін;

-дорослі мають тенденцію відкидати нові знання й досвід, якщо вони не відповідають їх системі цінностей та переконань;

- на навчальну діяльність дорослого можуть впливати часові, просторові, професійні, побутові й соціальні обмеження;

-дорослий, який навчається, висуває підвищені вимоги щодо якості й результатів навчання;

-найважливішим вторинним мотиваційним фактором необхідно розглядати можливість підвищення самооцінки в процесі навчання.

Першорядну роль в розробці програми навчання відіграє процес визначення потреб і вартості навчання персоналу в галузі клієнтоорієнтованості, що передбачає складання профілю компетенцій для кожної посади, оцінку відповідності цьому профілю співробітників, задіяння їх в процесі впровадження системи підвищення клієнтоорієнтованості, та прийняття рішення про розвиток компетенцій в ключових областях. 


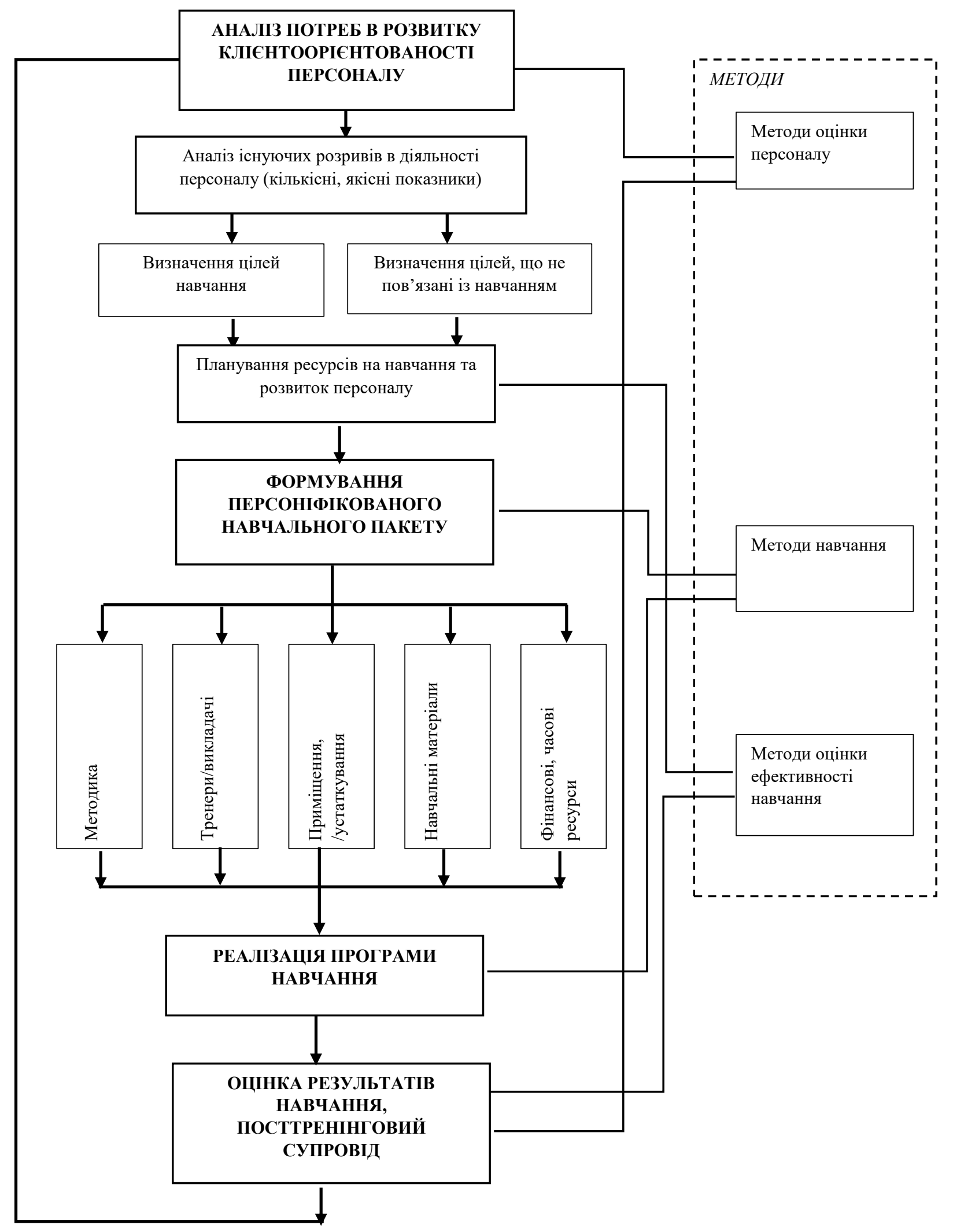

Рисунок 1 - Схема процесу розробки програми навчання персоналу в управлінні розвитком кліснтооріснтованості 
Програми навчання складаються відповідно до категорій слухачів, рівня підготовки, їх ролі в організаційній структурі підприємства. Навчання проводиться в групах і за індивідуальними планами. Обсяг освітніх програм залежить від цілей і завдань навчання, які визначаються за результатами попереднього аналізу рівня розвитку ключових компетенцій персоналу в галузі клієнтоорієнтованості.

У табл.1 представлено приклад структури модулю «Клієноорієнтований сервіс: будуємо екосистему» спеціальної програми підвищення кваліфікації для фітосанітарних інспекторів Головного управління Держпродспоживслужби у Вінницькій області, що була розроблена та реалізована Донецьким національним університетом імені Василя Стуса.

Таблиця 1

Структура модулю «Клісноорієнтований сервіс: будуємо екосистему»

\begin{tabular}{|c|c|}
\hline Елемент & Характеристика \\
\hline Мета & $\begin{array}{l}\text { Підвищення ефективності професійної діяльності і якості } \\
\text { обслуговування клієнтів за рахунок розвитку комунікативних } \\
\text { навичок та особистісного потенціалу слухачів }\end{array}$ \\
\hline Модулі & $\begin{array}{l}\text { Модуль 1. Клієнтооріснтованість: класичний і неокласичний } \\
\text { підхід. Екосистемна логіка побудови бізнесу. Основні поняття, типи } \\
\text { й складові клієнтоорієнтованості, клієнтоорієнтований сервіс. Аналіз } \\
\text { аудиторії кллінтів/споживачів послуг. Задоволеність } \\
\text { клієнтів/споживачів послуг: фактори й рівні забезпечення, методи } \\
\text { оцінки. } \\
\text { Модуль 2. Комунікаційна компетентність - умова ефективної } \\
\text { взаємодії із клієнтами/споживачами послуг. Види організаційних } \\
\text { комунікацій і їх характеристика. Модель «посилач-одержувач»: } \\
\text { втрата й спотворення інформації у спілкуванні. Особливості й бар'єри } \\
\text { внутрішньо-організаційних та міжособистісних комунікацій. Методи } \\
\text { й прийоми ефективної комунікації } 3 \text { різними типами } \\
\text { клієнтів/споживачів послуг. } \\
\text { Модуль 3. Емоційний інтелект: значення, оцінка, складові, } \\
\text { ознаки й шляхи розвитку. Діагностика особистихемоцій і причин } \\
\text { їх виникнення. Конфліктні ситуації з клієнтом/споживачем послуг: } \\
\text { типи «проблемних» клієнтів, рівні розвитку конфлікту, основні } \\
\text { правила роботи в зоні конфлікту. }\end{array}$ \\
\hline $\begin{array}{l}\text { Форми } \quad \text { проведення } \\
\text { занять }\end{array}$ & $\begin{array}{l}\text { Поєднання лекцій з практичними заняттями за системою "learning by } \\
\text { doing" (навчання в ході роботи): теоретичні аспекти ілюструються } \\
\text { прикладами } 3 \text { практики, використовуються тренінгові форми } \\
\text { навчання. }\end{array}$ \\
\hline Підсумкова атестація & $\begin{array}{l}\text { Виконання проекту «Розробка пропозиції щодо підвищення } \\
\text { клієнтоорієнтованості підприємства» }\end{array}$ \\
\hline
\end{tabular}

Навчальний процес на всіх його стадіях супроводжується консалтингом - корекція навчальних програм і їх адаптація під конкретних користувачів здійснюється як в процесі їх розробки, так і в ході навчання та при оцінці результатів окремих етапів навчання. У процесі розробки програми навчання враховуються виявлені потреби в навчанні й конкретні події, що відбулися останнім часом в організації, характер взаємовідносин у колективі, рівень взаємодії вищого керівництва й управлінського персоналу, особливості учасників групи, їх соціальний статус, професійна приналежність, вік. 
Обов'язковим компонентом реалізації програм підвищення кваліфікації співробітників $є$ питання оцінки ефективності 3 метою обгрунтування фінансових інвестицій і виявлення інструментів вдосконалення програм навчання. У цей час існує ряд підходів до проведення оцінки, які передбачають аналіз системи навчання й аналіз результатів навчання. Слід відзначити, що аналіз ефективності після проведення навчання носить констатуючий характер і не надає можливості оптимізувати ресурси, що витрачені на навчання. У зв'язку з цим вважаємо за доцільне вже на етапі розробки програми навчання провести дослідження мотивації персоналу з метою прогнозування результативності цього процесу.

3 метою підвищення ефективності процесів навчання доцільно розробити корпоративний Стандарт організації професійної підготовки, перепідготовки й підвищення кваліфікації персоналу. Стандарт повинен містити вимоги до форм, періодичності й фінансового забезпечення формування ключових компетенцій персоналу, до організації професійного навчання, оцінки його ефективності та звітності щодо виконання вимог стандарту. Метою навчання конкретних працівників $є$ успішне виконання ними посадових обов'язків. При цьому, персонал доцільно поділити на категорії, для кожної з яких повинні бути розроблені цільові програми професійної підготовки, що відображають бізнес-процеси підприємства. Обов'язковим елементом $\epsilon$ постійний контроль відповідності програм навчання профілю діяльності окремих категорій персоналу організації, а також контроль і регулювання фінансових потоків в області професійної підготовки персоналу. $\mathcal{C}$ очевидним, що діяльність з формування системи розвитку клієнтоорієнтованості персоналу може бути успішною тільки за активної участі в цьому процесі вищого керівництва, середньої ланки, виконавчого персоналу.

Висновки. Запропонований у роботі підхід дозволяє формалізувати процес розробки програм підвищення кваліфікації персоналу в області клієнтоорієнтованості в рамках існуючої кадрової політики підприємства. Процес навчання повинен бути інтегрований з діями щодо можливого оновлення кадрового складу, зміни організаційної структури, системи мотивації й оцінки персоналу, а також 3 іншими заходами 3 управління розвитком персоналу. Персоніфікований підхід до розробки програм навчання передбачає формування багаторівневої, відкритої системи, в якій навчання реалізується за індивідуальними освітніми траєкторіями відповідно до потреб і можливостей співробітника. Перспективним видається більш детальне вивчення проблем управління мотивацією до навчання, як одного 3 факторів забезпечення ефективності процесу підвищення кваліфікації персоналу.

\section{СПИСОК ВИКОРИСТАНИХ ДЖЕРЕЛ}

1. Эсаулова И.А. Развитие человеческих ресурсов: эволюция концепций и практики // Экономика труда. - 2018. - Том 5. - № 1. - С. 13-28.

2. Gilley J.W., Eggland S.A., Gilley A.M. Principles of Human Resource Development. Second edition. - Cambridge, MA: Perseus Publishing, 2002. - 482 p.

3. Джой-Меттьюз Д. Развитие человеческих ресурсов / Д. Джой-Меттьюз, Д. Меггинсон, М. Сюрте; пер. с англ. - М.:Эксмо, 2006. - 432 с.

4. Гугул О. Я. Теоретичні засади управління розвитком персоналу / О. Я. Гугул // Інноваціна економіка : всеукр. наук.-виробн. журн. - Тернопіль : ІКСГП НААН, 2013. № 6 (44). - С. 194-198.

5. Розвиток персоналу підприємства: підходи, сутність, моделі / Ю. А. Плугіна // Вісник економіки транспорту і промисловості. - 2013. - Вип. 42. - С. 323-327. 
6. Управління розвитком персоналу : [навч. посібник] / [Т.П. Збрицька, Г.О. Савченко, М.С. Татаревська] ; за заг. ред. М.С. Татаревської. - О. : Атлант, 2013. - 427 с. 7. Моргулець О. Б. Клієнтоорієнтована модель сервіс-менеджменту / О. Б. Моргулець // Науковий вісник Херсонського державного університету. Серія : Економічні науки. - Вип. 9, Ч. 4. - С. 111-115. https://er.knutd.edu.ua/bitstream/123456789/2930/1/20161104_104.pdf .

8. Продан I. О. Клієнтоорієнтований підхід як передумова конкурентоспроможності підприємства / І. О. Продан, Ю. І. Різник // Бізнес Інформ. - 2017. - № 1. - С. 308-313. Режим доступу: http://nbuv.gov.ua/UJRN/binf_2017_1_50 .

9. Романчукевич М.Й. Клієнтоорієнтованість як інструмент формування конкурентних переваг компаній. Інфраструктура ринку. 2018. № 21. С. 165-173. http://dspace.tneu.edu.ua/bitstream/316497/33237/1/30.pdf .

10. Боличева О.В. Проблематика досліджень феномена персоніфікації в освітньому процесі / О.В. Боличева // Вісник післядип. освіти: зб. наук. праць. - К., 2010. - Ч. 2. - С. 27-32.

11. Сивицька І.Г. Реалізація механізму взаємодії університету та промислового підприємства . Матеріали підсумкової наукової конференції Донецького національного університету за період 2005-2006 pр .: Економічна кібернетика (м Донецьк , квітень 2007 г .) / Відп . ред. Ю.Г. Лисенко . - Донецьк : ДонНУ , 2007. - С.50-52. 